\title{
PENINGKATAN KUALITAS pH, Fe DAN KEKERUHAN DARI AIR SUMUR GALI DENGAN METODE FILTRASI
}

\author{
Ahmad Mashadi ${ }^{1}$, Bambang Surendro ${ }^{2}$, Anis Rakhmawati ${ }^{3}$, Muhammad Amin ${ }^{4}$ \\ ${ }^{1}$ Jurusan Teknik Sipil, Fakultas Teknik, Universitas Tidar, J1 K.Suparman 39, Magelang 56116 \\ Email: hadi_mas751@yahoo.com \\ 2 Jurusan Teknik Sipil, Fakultas Teknik, Universitas Tidar, J1 K.Suparman 39, Magelang 56116 \\ Email : bsurendro@yahoo.com \\ ${ }^{3}$ Jurusan Teknik Sipil, Fakultas Teknik, Universitas Tidar, J1 K.Suparman 39, Magelang 56116 \\ Email : anisrakhmawati@untidar.ac.id \\ ${ }^{4}$ Jurusan Teknik Sipil, Fakultas Teknik, Universitas Tidar, J1 K.Suparman 39, Magelang 56116 \\ Email: muhammadamin@untidar.ac.id
}

\begin{abstract}
ABSTRAK
Air merupakan sumber daya yang dapat diperbaharui sementara itu kualitas air tanah tergantung sistem akifer dalam tanah dan kondisi lingkunan. Selain itu dalam kenyataan dijumpai bahwa pencemaran air tanah lebih cepat dibanding upaya pengolahan air tercemar menjadi air yang memenuhi syarat sehat. Untuk memenuhi kebutuhan manusia akan air bersih yang sehat mengacu Permenkes Nomor 416/MENKES/IX/1990. Sebagian besar masyarakat di Sumbersari, Purwodadi, Purworejo memanfaatkan air sumur gali untuk memenuhi kebutuhan air bersih. Di sebagian besar sumur gali milik penduduk kedalaman air sumur rata-rata muka air 2 (dua) meter dari permukaan tanah. Perubahan musim menjadikan kondisi air sumur berubah, di musim kemarau air bau dan berubah warna. Sampel awal kualitas air sumur terutama $\mathrm{pH}, \mathrm{Fe}$ dan kekeruhan belum memenuhi syarat air bersih. Penelitian dilakukan dengan mengambil sampel air sumur untuk mengetahui parameter fisik, kimia dengan metode filtrasi yaitu menggunakan media saringan pasir, batu apung, karbon aktif dan kerikil. Pelaksanaan penelitian cara saringan dengan variasi tebal media saringan.Tujuan penelitian ini untuk meningkatkan kualitas parameter air tersebut di atas $\mathrm{pH}$ agar memenuhi standar kesehatan. Hasil penelitian yang dilakukan dengan $\mathrm{k} 3$ tiga metode filtrasi dapat menaikkan kualitas air untuk $\mathrm{pH}$, sekaligus menurunkan Fe, menurunkan kekeruhan. Kesimpulan dari penelitian ini bahwa metode filtrasi dengan media saringan tertentu dapat meningkatkan kualitas air untuk parameter tertentu agar memenuhi syarat kesehatan.
\end{abstract}

Kata kunci: sumur gali, filtrasi, pH, Fe, kekeruhan.

\section{PENDAHULUAN}

\section{Latar Belakang}

Air merupakan kebutuhan utama dalam kehidupan dan merupakan sumber daya yang dapat diperbarui. Air yang dikonsumsi harus memenuhi standar kualitas mengacu Permenkes Nomor 416/MENKES/IX/1990. Air yang berkualitas meliputi kualitas fisik, kimia, dan bebas dari mikroorganisme (Slamet, 2009).

Untuk memenuhi kebutuhan sehari-hari masyarakat desa Sumbersari, Purwodadi, Purworejo menggunakan air sumur yang belum memenuhi syarat kesehatan, yaitu $\mathrm{pH}<6,5, \mathrm{Fe}>1$ dengan warna kuning. Konsekuensi dari penggunaan air yang tidak bersih dan hygiene dapat mengganggu kesehatan bagi yang mengkonsumsinya.

Salah satu sumber air bersih yang dimanfaatkan oleh manusia sebagian besar masih menggunakan air dari sumur gali. Air tanah merupakan sebagian air hujan yang mencapai permukaan bumi dan meresap ke dalam lapisan tanah dan menjadi air tanah. Sebelum mencapai lapisan tempat air tanah, air hujan akan menembus beberapa lapisan tanah dan menyebabkan air mengandung zat-zat mineral 
dalam konsentrasi tertentu. Zat-zat mineral tersebut, antara lain kalsium, magnesium dan logam berat seperti besi. Akibatnya, apabila kita menggunakan air sadah untuk mencuci, sabun tidak akan berbusa dan akan terbentuk endapan semacam kerak (Chandra, 2007).

Kualitas air sumur dapat dilihat pada musim hujan dan musim kemarau. Dimusim hujan air yang meresap ke dalam tanah dapat mengurangi konsentrasi pencemar yang ada. Pada musim kemarau air buangan sebagai limbah meresap kedalam tanah lebih dominan dapat menyebabkan mutu air menjadi tidak baik. Sumber air sumur gali di sebagian Desa Sumbersari, Purwodadi, Purworejo, kedalaman rata-rata muka air dari permukaan tanah antara 1 (satu) meter sampai 2 (dua) meter, dan dari hasil uji laboratorium pra-penelitian menunjukkan kandungan kadar besi $(\mathrm{Fe}), \mathrm{pH}$, kadar nitrit (NO2), kekeruhan, dan kesadahan (CaCO3) belum memenuhi syarat PERMENKES NO. 416 Tahun 1990.

Besi (Fe) merupakan logam yang banyak terdapat di dalam tanah, logam ini dibutuhkan dalam tubuh namun dalam jumlah kecil. Kelebihan logam Fe dalam tubuh dapat menimbulkan efek-efek kesehatan seperti serangan jantung, gangguan pembuluh darah bahkan kanker hati. Logam ini bersifat akumulatif terutama di organ penyaringan sehingga dapat mengganggu fungsi fisiologis tubuh. Nilai estetika juga dapat dirusak oleh keberadaan logam ini karena dapat menimbulkan bercak-bercak hitam pada pakaian. Air yang tercemar oleh logam ini biasanya nampak pada intensitas warna yang tinggi pada air, berwarna kuning bahkan berwarna merah kecoklatan, dan terasa pahit atau masam (Wardhana, 2004).

Derajat keasaman $(\mathrm{pH})$ digunakan untuk menyatakan tingkat keasaman atau kebasaan oleh suatu larutan. Ia didefinisikan sebagai kologaritma aktivitas ion hidrogen $(\mathrm{H}+)$ yang terlarut. Koefisien aktivitas ion hidrogen tidak dapat diukur secara eksperimental, sehingga nilainya didasarkan pada perhitungan teoretis, tinggi rendahnya $\mathrm{pH}$ air dapat mempengaruhi rasa air (https://id.wikipedia.org/wiki/PH)

Kesadahan perairan dikelompokkan dalam kesadan kalsium dan kesadahan magnesium Kesadahan karbonat sangat sensitive terhadap panas dan mengendap dengan mudah pada suhu tinggi.Air permukaan biasanya memiliki nilai kesadahan yang lebih rendah dibanding keasadahan pada air tanah. Kesadahan air berkaitan dengan kemampuan air membentuk busa. Semakin besar kesadahan air semakin sulit bagi sabun untuk membentuk busa karena terjadi presipitasi (Efendi, H, 2003).

Menurut PERMENKES No. 416 tahun 1990, kadar Fe dalam air bersih maksimum yang diperbolehkan adalah $1 \mathrm{mg} / 1$, batas $\mathrm{pH}$ air layak minum berkisar 6.5-9.0, angka kesadahan maksimum $500 \mathrm{mg} / \mathrm{l}$.

Metode yang digunakan untuk menurunkan kadar dari parameter air yang ada di dalam air ada berbagai macam seperti: filtrasi, koagulasi/flokulasi dan sedimentasi. Pada penelitian ini metode yang digunakan untuk menurunkan kadar besi $(\mathrm{Fe})$ dan meningkatkan derajat keasaman $(\mathrm{pH})$ dan menurunkan kesadahan adalah metode filtrasi.

\section{Rumusan Masalah}

Berdasarkan kondisi muka air sumur gali di lokasi penelitian termasuk sangat dangkal sedalam 1(satu) sampai 2(dua) meter dari muka tanah. Air dalam sumur termasuk air permukaan yang kualitas airnya kurang baik yang disebabkan sangat terpengaruh oleh infiltrasi air buangan. Air buangan yang merupakan limbah inilah yang dapat menjadi sumber pencemaran dari sumur sendiri. Berdasar keadaan inilah disampaikan rumusan masalah sebagai berikut :

1. Bagaimana kualitas air dari sumur gali di lokasi penelitian,

2. Parameter air apa saja yang belum memenuhi syarat,

3. Apakah treatment air bisa meningkatkan kualitas air.

\section{Tujuan Penelitian}


1. Untuk mengetahui kualitas air di Sumbersari, Purwodadi, Purworejo.

2. Untuk mengetahui parameter air yang perlu diperbaiki.

3. Mengetahui pengaruh treatment dalam meningkatkan kualitas air.

\section{LANDASAN TEORI}

Dari pengamatan beberapa penelitian sebelumnya yang dilakukan para peneliti Manalu, 2013 untuk memperbaiki kesadahan, Qudus,2014 dengan teknik pengolahan dengan saringan pasir lambat dan Hardini dan Kusumaningrum, 2011 menggunakan pasir, zeolit dan karbon aktif untuk memperbaiki kualitas air. Dalam penelitian terbut menunjukkan bahwa penggunaan tebal filter, jenis filter dapat meningkatkan kualitas air. Variasi tebal filter bersusun diharapkan lebih baik meningkatkan kualitas air, sekaligus sebagai alat untuk pengolahan air sumur. Bahan filter yang akan dipakai tersebut adalah bahan filter yang dapat diperoleh di toko kimia dengan biaya yang masih terjangkau.

\section{Teknik Sedimentasi}

Sedimentasi merupakan suatu proses pengendapan partikel-partikel padat yang tersuspensif dalam cairan/zat cair karena pengaruh gravitasi. Proses sedimentasi terjadi apabila partikel tersebut mempunyai berat jenis yang lebih besar dari air sehingga secara gravitasi partikel tersebut tenggelam.

\section{Koaguliasi/Flokulasi}

Koagulasi merupakan proses pengumpulan partikel-partikel halus yang tidak dapat diendapkan secara gravitasi menjadi partikel yang lebih besar dengan menambah bahan koagulan. Partikel-partikel tersebut kemudian dihilangkan melalui proses sedimentasi dan filtrasi (Dendy Primanandi, 2015).

\section{Filtrasi}

Filtrasi atau penyaringan adalah suatu proses untuk menghilangkan zat padat tersuspensif diukur dengan kekeruhan dari air melalui media berpori. Penyaringan melalui media berpori terjadi dengan cara menghambat partikel-partikel ke dalam ruang pori sehingga terjadi pengumpulan dan tumpukan partikel tersebut pada permukaan butiran media. Dengan tumpukan partikel yang melekat pada butiran media ini akan membuat air tidak keruh dan menjadi lebih bersih.

\section{METODOLOGI PENELITIAN}

\section{Alur Penelitian}

Sesudah memahami tentang latar belakang, masalah, tujuan dan landasan teori dilakukan langkah penelitian. Langkah penelitian ini sebagai pedoman penelitian di lapangan sesuai Gambar 3.1

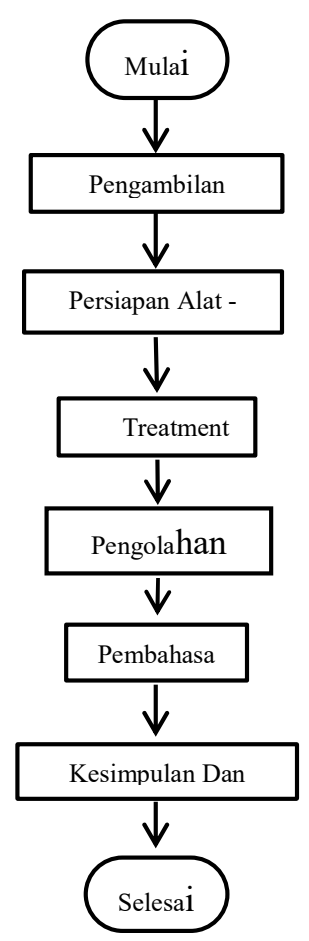




\section{Gambar 1. Alur Penelitian}

\section{Rancangan Penelitian}

Penelitian ini untuk menggambarkan hubungan antara variasi tebal media filter, lama proses aerasi terhadap peningkatan kualitas air. Oleh karena itu penelitian ini bersifat pengamatan langsung dan pengambilan sampel. Untuk memudahkan penelitian dibuat kerangka penelitian, sehingga dapat dilihat hubungan antara variable-variabel yang diteliti terhadap peningkatan $\mathrm{Ph}$, penurunan kadar besi (Fe) dan penurunan kesadahan di dalam air, seperti ditunjukkan pada Gambar 3.2.

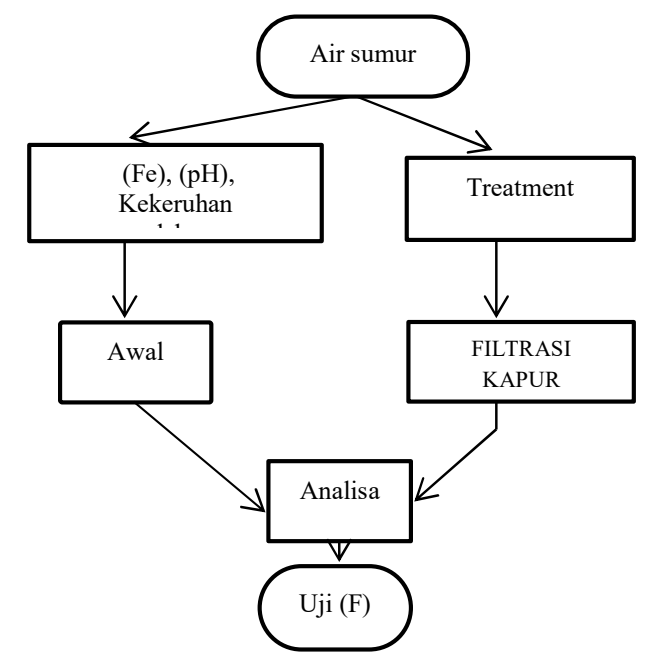

\section{Alat penelitian}

\section{Gambar 2. Kerangka Pikir}

1. Alat filtrasi

Alat filtrasi terbuat dari pipa PVC berdiameter 6 inchi dan tinggi $100 \mathrm{~cm}$, dilengkapi outlet model leher angsa sebagai output air sesudah melewati alat filtrasi.

2. Alat up flow

Alat up flow terbuat dari pipa PVC berdiameter 6 inchi dengan tinggi $100 \mathrm{~cm}$, memiliki outlet yang terbuat dari pipa PVC $1 / 2$ inchi sebagai output setelah melewati media filtrasi, untuk inlet terbuat dari pipa PVC $1 / 2$ inchi langsung disalurkan dari tandon.

3. Bahan media filter yang digunakan antara lain: pasir, karbon aktif, zeolit, kerikil. Untuk pasir dan kerikil dicuci bersih dan dikeringkan diterik matahari.

4. Alat penelitin yang dimaksud dalam peneltian ini apat dilihat pada Gambar 3

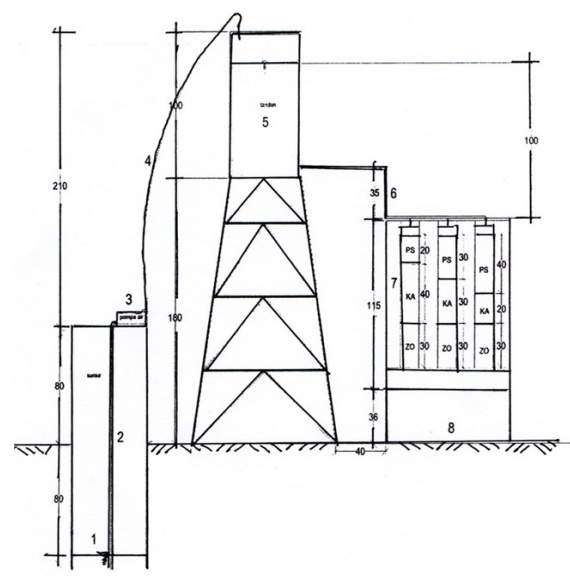

Keterangan

1, Muka Air Sumur

2, Pipa PVC

3. Pompa Listrik

4. Selang Air ke bak tando

5.Bak Tando Air

6. Pipa distribusi dengan Kran

7. Alat Filtrasi

8. Tempat Alat Filtrasi 
Gambar 3. Rangkaian Alat Penelitian

5. Variasi Tebal Media Filter

Tebal filter F1, F2 dan F3 untuk penelitian dengan metode filtrasi ditunjukkan pada Gambar 4.

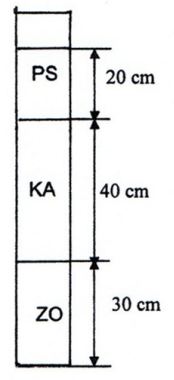

F1

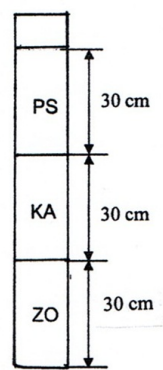

F2

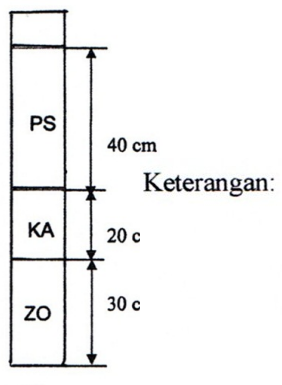

F3

$$
\begin{aligned}
\mathrm{PA} & =\text { Pasir } \\
\mathrm{KA} & =\text { Karbon Aktif }
\end{aligned}
$$

ZO $=:$ Zeolit

Gambar 4. Susunan Tebal Bahan Filter F1 F2 dan F3

\section{HASIL DAN PEMBAHASAN}

\section{Hasil Uji Laboratorium Metode Filtrasi}

a. Kadar Fe dan Filter, lihat Tabel 1 dan Gambar 5

Tabel 1. Hasil Lab Kadar Fe Sampel Air

\begin{tabular}{|c|c|c|c|c|}
\hline \multirow{2}{*}{ No. Sampel } & \multicolumn{4}{|c|}{ Hasil Lab. Sampel Air Fe (besi) } \\
\cline { 2 - 5 } & $\begin{array}{c}\text { Kontrol } \\
(\mathrm{mg} / \mathrm{l})\end{array}$ & $\begin{array}{c}\text { Filter-1 } \\
(\mathrm{mg} / \mathrm{l})\end{array}$ & $\begin{array}{c}\text { Filter-2 } \\
(\mathrm{mg} / \mathrm{l})\end{array}$ & $\begin{array}{c}\text { Filter-3 } \\
(\mathrm{mg} / \mathrm{l})\end{array}$ \\
\cline { 2 - 5 } & 1 & 2 & 3 & 4 \\
\hline 1 & 4.937 & 0.46 & 0.47 & 0.6 \\
\hline 2 & 4.937 & 0.43 & 0.45 & 0.6 \\
\hline 3 & 4.937 & 0.43 & 0.42 & 0.61 \\
\hline Rerata & 4.937 & 0.44 & 0.45 & 0.60 \\
\hline
\end{tabular}

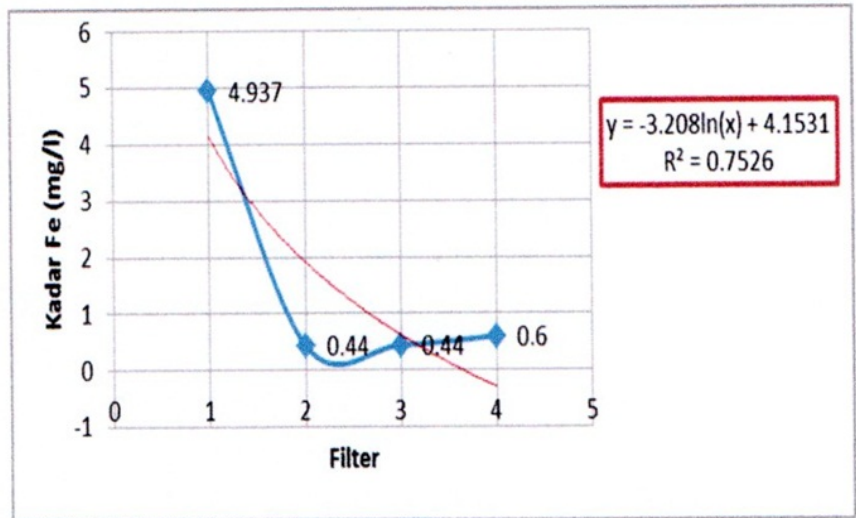

Gambar 5. Grafik hubungan Fe-filter 
Jurnal Riset Rekayasa Sipil Universitas Sebelas Maret 10 Maret 2018 ISSN 2579-7999

b. Kadar $\mathrm{pH}$ dan filter, lihat Tabel 2 dan Gambar 6.

Tabel 2. Hasil Lab Kadar pH Sampel Air

\begin{tabular}{|c|c|c|c|c|}
\hline \multirow{2}{*}{ No. Sampel } & \multicolumn{4}{|c|}{ Hasil Lab. Sampel Air $\mathrm{pH}$} \\
\cline { 2 - 5 } & $\begin{array}{c}\text { Kontrol } \\
(\mathrm{mg} / \mathrm{l})\end{array}$ & $\begin{array}{c}\text { Filter-1 } \\
(\mathrm{mg} / \mathrm{l})\end{array}$ & $\begin{array}{c}\text { Filter-2 } \\
(\mathrm{mg} / \mathrm{l})\end{array}$ & $\begin{array}{c}\text { Filter-3 } \\
(\mathrm{mg} /)\end{array}$ \\
\cline { 2 - 5 } & 1 & 2 & 3 & 4 \\
\hline 1 & 6.23 & 7.49 & 7.53 & 7.75 \\
\hline 2 & 6.23 & 7.41 & 7.48 & 7.7 \\
\hline 3 & 6.23 & 7.39 & 7.45 & 7.74 \\
\hline Rerata & 6.23 & 7.43 & 7.49 & 7.73 \\
\hline
\end{tabular}

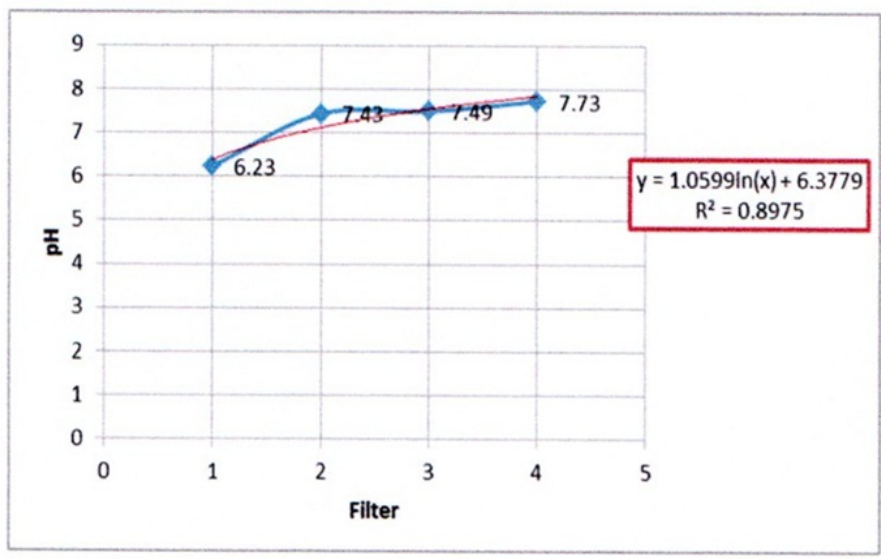

c. Kadar kesadahan dan filter, lihat pada Tabel 3 dan Gambar 7.

Tabel 3. Hasil Lab Kesadahan Sampel Air

\begin{tabular}{|c|c|c|c|c|}
\hline \multirow{3}{*}{ No. Sampel } & \multicolumn{4}{|c|}{ Hasil Lab. Sampel Air kesadahan } \\
\cline { 2 - 5 } & $\begin{array}{c}\text { Kontrol } \\
(\mathrm{mg} / \mathrm{l})\end{array}$ & $\begin{array}{c}\text { Filter-1 } \\
(\mathrm{mg} / \mathrm{l})\end{array}$ & $\begin{array}{c}\text { Filter-2 } \\
(\mathrm{mg} / \mathrm{l})\end{array}$ & $\begin{array}{c}\text { Filter-3 } \\
(\mathrm{mg} / \mathrm{l})\end{array}$ \\
\cline { 2 - 5 } & 1 & 2 & 3 & 4 \\
\hline 1 & 158,6 & 100 & 141 & 154 \\
\hline 2 & 158.6 & 117 & 143 & 154 \\
\hline 3 & 158.6 & 118 & 150 & 156 \\
\hline Rerata & 158.6 & 111.67 & 144.67 & 154.67 \\
\hline
\end{tabular}




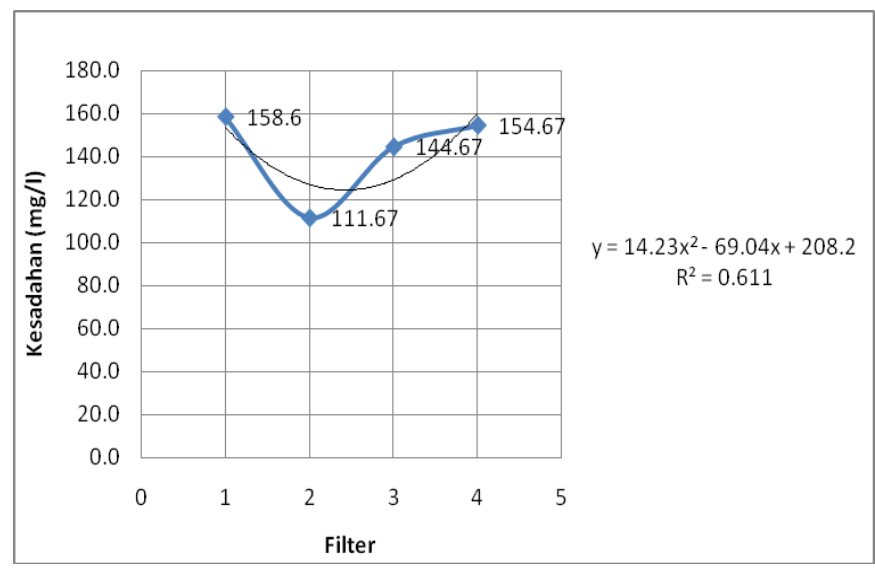

Gambar 7. Grafik hubungan kesadahan dan filter

\section{Anova}

a. Berdasar Tabel 1 dianalisis Anova untuk parameter Fe (besi), ditunjukkan pada Tabel 4

Tabel 4. Uji Statistik Anova kadar Fe

\begin{tabular}{|c|c|c|c|c|c|c|}
\hline \multicolumn{2}{|c|}{ Anova: Single Factor } & \multirow[b]{3}{*}{ Sum } & \multirow[b]{3}{*}{ Average } & \multirow[b]{3}{*}{ Variance } & & \\
\hline \multicolumn{2}{|l|}{ SUMMARY } & & & & & \\
\hline Groups & Count & & & & & \\
\hline Column 1 & 3 & 0.24 & 0.08 & 0.0009 & & \\
\hline Column 2 & 3 & 0.09 & 0.03 & $1 \mathrm{E}-04$ & & \\
\hline Column 3 & 3 & 0.02 & 0.006667 & 3.33E-05 & & \\
\hline \multicolumn{2}{|l|}{ ANOVA } & & & & & \\
\hline Source of Varia & SS & $d f$ & MS & $F$ & P-value & Fcrit \\
\hline Between ' & 0.008422 & 2 & 0.004211 & 12.22581 & 0.007649 & 5.143253 \\
\hline Within $\mathrm{Gr}$ & 0.002067 & 6 & 0.000344 & & & \\
\hline Total & 0.010489 & 8 & & & & \\
\hline
\end{tabular}

b. Berdasar Tabel 2 dianalisis Anova untuk parameter $\mathrm{pH}$, ditunjukkan pada Tabel 5

Tabel 5. Uji Statistik Anova kadar $\mathrm{pH}$

\begin{tabular}{|c|c|c|c|c|c|c|}
\hline \multicolumn{2}{|c|}{ Anova: Single Factor } & \multirow[b]{3}{*}{ Sum } & \multirow[b]{3}{*}{ Average } & \multirow[b]{3}{*}{ Variance } & & \\
\hline \multicolumn{2}{|l|}{ SUMMARY } & & & & & \\
\hline Groups & Count & & & & & \\
\hline Column 1 & 3 & 21.32 & 7.106667 & 0.008033 & & \\
\hline Column 2 & 3 & 20.55 & 6.85 & 0.0201 & & \\
\hline Column 3 & 3 & 20.42 & 6.806667 & 0.004133 & & \\
\hline ANOVA & & & & & & \\
\hline Source of Varia & SS & $d f$ & MS & $F$ & P-value & F crit \\
\hline Between I & 0.157756 & 2 & 0.078878 & 7.333678 & 0.024468 & 5.143253 \\
\hline Within Grı & 0.064533 & 6 & 0.010756 & & & \\
\hline Total & 0.222289 & 8 & & & & \\
\hline
\end{tabular}

c. Berdasar Tabel 3 dianaiisis Anova untuk parameter kesadahan, ditunjukkan pada Tabel 5 
Tabel 6. Uji Statistik Anova Kesadahan

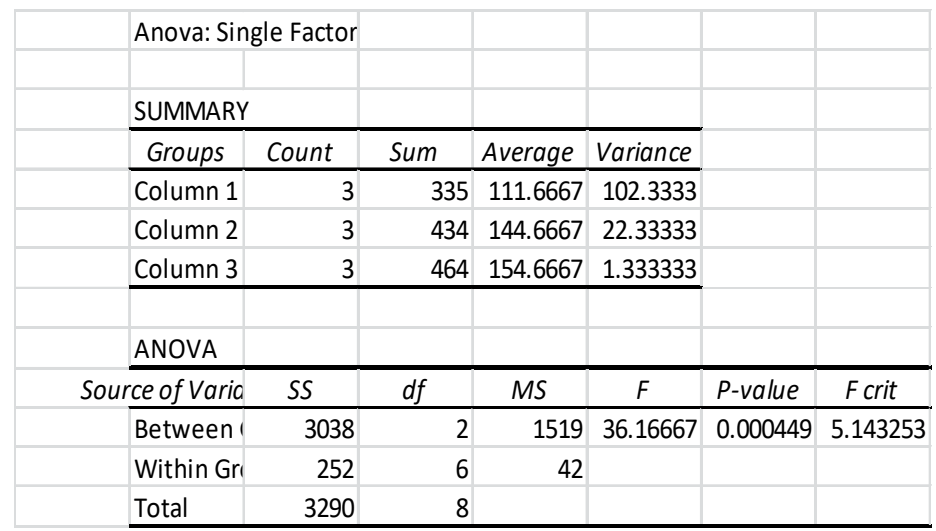

\section{Bakteriologi}

Untuk memanfaatkan momentum pada penelitian ini sekaligus dilaksanakan pengambilan sampel untuk mengetahui uji laboratorium bakteriologi di Balai Laboratorium Kesehatan Yogyakarta dengan hasil yang dapat dilihat pada Tabel 4.

Tabel 4. Hasil Uji Coli fom

\begin{tabular}{|c|c|c|c|c|c|}
\hline No. & Lokasi & Parameter & Satuan & Hasil Uji & Baku Mutu \\
\hline 1 & Ngabean 1 & coliform & MPN/100ml & $<1,8$ & 50 \\
\hline 2 & Dhudhuan 1 & coliform & MPN/100ml & $>1600$ & 50 \\
\hline 3 & Sikepan 1 & coliform & MPN/100ml & 4 & 50 \\
\hline 4 & Beji & coliform & MPN/100ml & $>1600$ & 50 \\
\hline 5 & Sumber Kidul & coliform & MPN/100ml & 4.5 & 50 \\
\hline 6 & Ngabean 2 & coliform & MPN/100ml & 79 & 50 \\
\hline 7 & Sikepan 2 & coliform & MPN/100ml & 1600 & 50 \\
\hline 8 & Dhudhuan 2 & coliform & MPN/100ml & 79 & 50 \\
\hline
\end{tabular}

\section{Pembahasan}

a. Fe.

$\mathrm{y}=-0.385 \ln (\mathrm{x})+0.4669, \mathrm{R}^{2}=0.8711$. Hasil uji Anova $\mathrm{F}$ hitung 12,22581 > F kritis 5,1432528, filter dapat menurunkan $\mathrm{Fe}$

b. $\mathrm{pH}$

$\mathrm{y}=0.3994 \ln (\mathrm{x})+6.4335, \mathrm{R}^{2}=0.4317$. Hasil uji Anova $\mathrm{F}$ hitung 7,333678 $>\mathrm{F}$ kritis 5,1432528, filter dapat menaikkan $\mathrm{pH}$.

c. Kekeruhan

$\mathrm{y}=14.025 \mathrm{x}^{2}-67.922 \mathrm{x}+207.22$, dengan $\mathrm{R}^{2}=0.5934$. Hasil uji Anova $\mathrm{F}$ hitung 7,960763 $>\mathrm{F}$ kritis 5,1432528 , filter menurunkan kekeruhan

d. Bakteriologi

Berdasarkan Tabel 4 disimpulkan bahwa kualitas air di lokasi penelitian secara bakteriologis belum sesuai PERMENKES No 416/MEN.KES/PER/IX/1990. Oleh karena itu diperlukan pengolahan yang lebih baik untuk menurunkan bakteri coli.

\section{KESIMPULAN DAN SARAN}

\section{Kesimpulan}


a. Variasi filter berpengaruh pada peningkatan $\mathrm{pH}$, penurunan $\mathrm{Fe}$, dan penurunan kekeruhan.

b. Penurunan Fe yang efektif menggunakan filter 3 dengan ketebalan pasir lebih besar dari filter yang lain.

c. Peningkatan $\mathrm{pH}$ yang efektif menggunakan filter 1 dengan ketebalan karbon aktif yang lebih besar dari filter yang lain.

\section{Saran}

Berdasarkan hasil penelitian yang diperoleh, maka penyusun memberikan saran-saran sebagai berikut :

1. Penelitian dapat dilanjutkan menggunakan debit yang kecil dan waktu yang lebih lama untuk mengetahui kemampuan optimal dari filter yang dipakai.

2. Penelitian dapat dilanjutkan dengan mempertimbangkan aspek kepadatan lapisan filter.

3. Penelitian dapat dilanjutkan dengan mempertimbangkan aspek musim.

4. Penelitian dapat dilanjutkan dengan mencari alternatif bahan filter yang mudah didapat untuk kepentingan masyarakat setempat.

\section{DAFTAR PUSTAKA}

Chandra, B., 2007, Kesehatan Lingkungan, Penerbit EGC, Jakarta. Effendi,H., 2003, Telaah Kualitas Air Bagi Pengelolaan Sumberdaya dan Lingkungan, Kanisius, Yogyakarta. https://id.wikipedia.org/wiki/PH diakses pada hari jumat 21 Juli 2017, pukul 20.30 wib.

Hardini dan Karnaningrum, 2011, Peningkatan Kualitas Air Sumur Gali Menjadi Air Bersih Menggunakan Filter Zeolit, dan Karbon Aktif: Studi Kasus Air Sumur Gali Permukiman Desa Banjar Po Sidoarjo, ITS, Surabaya.

Manalu, A, A, 2013, Pengaruh Filter Dan Lama Kontak Terhadap Keasdahan Aaair dari Gunung Kapur Clampea. Fakultas Perikanan dan Ilmu Kelautan Institut Pertanian Bogor, Bogor;

Primanandi, D, 2015. Sedimentasi dan koagulasi. ITB, Bandung

Permenkes No.416/MenKes/Per/IX/1990 tentang Pengawasan Syarat-syarat dan Pengawasan Kualitas Air, Jakarta.

Qudus, R, 2014, Teknik Pengolahan Air Bersih dengan Sistem Saringan Pasir Lambat yang bersumber dari Sungai Musi. Jurus Teknik Sipil, Universitas Sriwijaya, Palembang

Slamet, J., S., 2009, Kesehatan Lingkungan, Universitas Gadjah Mada, Yogyakarta.

Wardhana, W., A., 2004, Dampak Pencemaran Lingkungan, Cetakan keempat, Penerbit ANDI, Yogyakarta. 